\title{
CONSULTING IN THE UKRAINIAN MARKET OF SERVICES AND ITS COMPETITIVE ADVANTAGES
}

\author{
Natalia Yevtushenko', Tatiana Halimon ${ }^{2}$
}

\begin{abstract}
The article summarizes the arguments and counterarguments about the peculiarities of formation of competitive advantages on the services market in Ukraine on the example of consulting. Assessment of the development of consulting services market in Ukraine was conducted for ten years $(2010 ; 2011 ; 2012 ; 2013 ; 2013$; $2014 ; 2015 ; 2016 ; 2017 ; 2018 ; 2019,2020)$. Methodology. The use of methods of analysis, synthesis and graphical representation allowed for a theoretical study of the formation of competitive advantages. The use of methods of economic, heuristic and strategic analysis became the basis for estimating the market of consulting services in Ukraine and working out practical recommendations for its development. Results. The author's understanding of the concept of "competitive advantages of the company", the factors of their formation and described the relationship of competitive strategies with the process of their formation. Analysis of the market of consulting services in Ukraine revealed its immaturity, exacerbated by the economic crisis, as well as the institutional vulnerability of consulting. The reasons of unstable demand for consulting services are described. According to the results of the expert assessment the Top 15 Ukrainian consulting companies (2020) out of 102 were determined. The leadership matrix of these companies is built depending on their role in the target market, taking into account the typology of competitive strategies of F. Kotler. The analysis showed the transformation of consulting in Ukraine under the influence of the COVID-19 pandemic and the broad interest in digital and HR consulting. Practical recommendations for the development of the market of consulting services in Ukraine are presented. Practical implications. It is proposed to include the following factors in the formation of the competitive advantages of the consulting company: the quality of services, competence of consultants and productivity of the company. The main competitive advantage is the competence of consultants, the level of which affects the quality of services, the results of the company and its customers. To strengthen the competitive advantage it is recommended to use the standard of consulting services in the activities of Ukrainian companies. Value/originality. The results of the study can be useful for any consulting company wishing to improve its competitiveness and expand the market for its services.
\end{abstract}

Key words: consulting, competitive advantages, competencies, consulting interaction, service, company.

JEL Classification: G29, 017, 030

\section{Introduction}

The progressive development of the world economy is associated with transformational processes and is characterized by the orientation of production on innovation and high science intensity. The transition to new economic relations of entities contributed to the development of various forms of ownership and methods of management of business processes, finance, material resources and human capital. Consulting is an alternative tool in this process. Thus, between 2015 and 2020 , the average annual growth rate of consulting in the global market was $10 \%$. The demand for consulting is driven by economic growth in emerging markets, regulatory reforms in the financial sector, outsourcing of support operations in low-cost economies and public investment.

Professional consultants of large excellent consulting companies are involved in solving the problem situations of client companies, helping them to respond quickly to changes in the external environment and to adapt to them. The services of management consulting are in great demand, and include solutions for improving: administrative management, strategic and organizational planning; business processes

\footnotetext{
Corresponding author:

${ }^{1}$ State University of Telecommunications, Ukraine.

E-mail: evtushtnko.13.nat@gmail.com

ORCID: https://orcid.org/0000-0001-8865-8365

${ }^{2}$ State University of Telecommunications, Ukraine.

E-mail: tnx@ukr.net

ORCID: https://orcid.org/0000-0002-9194-4108
} 
using innovative technologies, competitive position, productivity, product quality and human resources. A key driver and fast-growing segment of the management consulting market is digital consulting, whose activities have made it possible to integrate analytics, cloud technology and social media into existing business models of client companies with their subsequent optimization. Digital consulting has gained even more momentum since the COVID-19 pandemic crisis, allowing for an even greater variety of IT solution options.

Thus, the global consulting market, on the one hand, annually increases its turnover and contributes to the formation of other service markets (cybersecurity, IT transformation, CRM systems, social media marketing, etc.). On the other hand, the services of global consulting companies lead to qualitative changes in the activities of client companies, which increases their level of competitiveness. Ultimately, the development of economic entities in a particular country affects the growth of GDP and the level of well-being of the population.

Consulting in Ukraine is also designed to help companies solve a number of complex economic and management problems. However, in most cases, the activities of Ukrainian consulting companies themselves do not provide a sustainable competitive advantage. This leads to the development of aggressive competition in the market of consulting services, where Ukrainian companies tend to provide onetime low-quality consulting services at high prices. That is why companies-customers often resort to the services of international consulting companies. As a consequence, the study of peculiarities of formation of competitive advantages of consulting companies in the market of services in Ukraine is relevant.

\section{Literature review}

\subsection{Competitive advantages of the enterprise: a theoretical aspect}

Technologies of formation of competitive advantages of economic entities at different levels of economic system development are considered and developed in the works of many foreign and domestic scientists. Analysis of the scientific literature on the content of the definition of "competitive advantage of an enterprise" revealed a variety of views of scientists on this issue.

Most scientists support the view of classical economists, including the famous foreign expert in the field of strategic management and marketing Jean-Jacques Lamben (Lamben, 2008), who defines competitive advantage as a feature or property (attributes) of the product or brand, which gives an enterprise an advantage over direct competitors.
The famous foreign scientist M. Porter (Porter, 2005) argues that competitive advantage is a combination of factors that determine the success or failure of the enterprise in the competitive struggle, as well as the productivity of its use of resources. It is necessary to agree with this definition, because the productivity of the use of resources, depends on the ability of the enterprise to implement an effective system of personnel management.

Some researchers describe the essence of competitive advantages through characteristics that do not fully reveal the content of this economic category.

Within the classical concept, L. Balabanova (Balabanova, 2002) defines competitive advantages as the strengths of a company that provide superiority over competitors and are important for the target market. In the same direction, Z. Dolzhansky and T. Zagorna (Dolzhansky \& Zagorna, 2006) characterize the concept of "competitive advantages of the enterprise" as the level of efficient use of all types of resources available to the firm (as well as for future consumption).

According to G. Fathudinov (Fathudinov, 2004), competitive advantage is any exceptional value that a system possesses and which gives it an advantage over competitors. However, the author does not disclose the structure of the enterprise value and the nature of its existence in relation to competitors, does not specify the characteristics of the exceptional value. According to A. Voychak and G. Kamushnikov (Voychak \& Kamushnikov, 2005), competitive advantages refers to characteristics or properties that provide an enterprise with an advantage over direct competitors. However, the authors do not provide a meaningful description of competitive advantages and do not indicate the attributes of properties that can provide competitive leadership.

S. Bondarenko and M. Lisovskyy (Bondarenko \& Lisovsky, 2017) reveal competitive advantage as a relative category, which is inherent in the ability to adapt to changes at a certain level of stability and efficiency, together determining the possibilities for successful functioning of the enterprise in a competitive environment. However, the authors do not explain the content of the category that determines the competitive advantage, and do not give the forms of its manifestation.

In the works of other scientists the concept of "competitive advantages" is described through economic characteristics, measured by financial indicators (quantitative), and such indicators (qualitative), which demonstrate the results of the enterprise in functional areas. Thus, researchers K. Elin (Elin, 2012) and A. Levitska (Levitska, 2012) interpret competitive advantages as a factor (or a set of factors) that directly or indirectly determines a stable or growing choice of market participants in favor of the company, allows 
obtaining a certain economic effect, increases or stabilizes profits.

A similar point of view noted by L. Azoev and A. Chelenkov (Azoev \& Chelenkov, 2000), presents competitive advantages as a manifestation of superiority over competitors in economic, technical and organizational spheres of enterprise activity, can be measured by economic indicators (additional income, higher profitability, market share, sales volume). Famous Ukrainian scientists E. Gudz (Gudz, 2013) and N. Teslyuk (Teslyuk, 2005) indicated qualitative or quantitative indicators of its position in the market, which ultimately provide the enterprise with income that exceeds the industry average, as well as the corresponding indicators of competitors.

Despite the different points of view on the formation of the concept of "competitive advantage" on the model of their management, these studies remain relevant, especially in the global transformation of the economies of many countries with the active introduction of information technologies.

\subsection{Developmental counseling theory in the literature review}

The consulting industry dates back to the late $19^{\text {th }}$ century, when the world's first modern consulting firms were founded. MIT chemist Arthur Dehon Little is considered the founder of the first production management consulting company. In 1886, he and his colleague Roger B. Griffin founded a consulting company, Arthur D. Little, Inc., which flourished as an independent company for more than a century. In 2002, it became part of the Paris-based consulting firm Altran. (Science History Institute, 2017)

A new field of management consulting emerged in American universities more than a century ago to support the commercial world struggling with the unprecedented growth of the industrial revolution. So James O. McKinsey (Seo Solution, 2016), a professor at the University of Chicago, founded McKinsey and Company in 1926, which has entered the history books as the world's first "clean" management consulting company. This consulting company still holds a leading position in the world consulting, and it is almost impossible to find an equal competitor for it.

The increasing role of management consulting in the global economy is associated with the extreme complexity of management decision-making conditions as a result of increased uncertainty in the business environment and increased asymmetry of information. A significant contribution to the study of modern consulting, its theoretical, methodological and practical aspects was made by well-known foreign researchers such as: E. Shane (Shane, 1969), L. Greiner, R. Metzger (Greiner \& Metzger, 1983), R. Yuksvyarav (Yuksvyarav, Khabakuk \&
Leimann, 1988), T. Clark (Clark, 1995), M. Kipping (Kipping, 1999), V. Aleshnikova (Aleshnikova, 2000), M. Kubr (Kubr, 2002), G. Marinko (Marinko, 2005), S. MacDonald (MacDonald, 2006), P. Block (Block, 2007), J. O'Mahony (O'Mahony, 2010), A. Blinov (Blinov \& Dresvyannikov, 2013) and others. Scientists presented the conceptual foundations of management consulting, identified the features of functioning and development, identified the weaknesses of management consulting and its impact on the economic development of client enterprises, proposed promising areas of external and internal consulting, taking into account the professionalism of the consultants.

At the beginning of 2000, such Ukrainian scientists as O. Trofimova (Trofimova, 2002), V. Verba (Verba, 2012), T. Reshetnyak (Verba \& Reshetnyak, 2000) presented the research format of management consulting in the Ukrainian service market. These scientists substantiated the methodological, organizational and economic aspects of the interaction of consulting company interaction in the client service process. They formed the conceptual apparatus of consulting and types of its services.

Later, Ukrainian scientists described either general issues of the consulting services market in Ukraine (S.V. Kozachenko, V.E. Novitskyi, O.S. Dovgy) or separate directions of consulting such as: implementation of a consulting project (Rybakova, 2010), formation and implementation of consulting support for enterprises (Davidenko, 2006), behavior of subjects of the consulting services market: goals and principles (O.A. Marchenko) and more.

The study by N. Yevtushenko (Yevtushenko, 2019) presents a modern perspective on the formation and implementation of the organizational and economic mechanism of internal and external consulting. She substantiated the need to introduce the concept of "consulting interaction" in the consultation process, which is considered as a professional communicative process between the subjects of economic relations in the communicative space on the solution of problem situations of enterprises-customers of consulting services in accordance with the improvement of their capacity for management, functioning and development. N. Yevtushenko said that under such conditions, consulting is a process agreed with the client to create intellectual products by professional consultants with their subsequent implementation in the activities of clients.

In the course of the research it was found that today the most important problem for Ukrainian consulting companies is the problem of their survival in the service market, where the leading positions occupied by international consulting companies. We believe that one of the main directions for solving this problem is the study of theoretical and methodological aspects 
of the formation of competitive advantages of consulting companies, as well as the development of practical recommendations for their formation, which confirms the relevance of this study.

The purpose of the article is to study the theoretical and methodological aspects of the formation of companies' competitive advantages, to develop on this basis, practical recommendations for the formation of competitive advantages on the example of consulting companies in the Ukrainian service market, taking into account their functioning and development trends.

\section{Methodology}

The analysis of the economic category "competitive advantage of the company"indicates the ambiguity of scientists' views on the content of this concept. We propose to define the concept of "competitive advantage" as a system of factors that will help the company to take and hold the best competitive position in the market compared to other companies in accordance with the specifics of the organization of competitive behavior, which together will ensure the successful functioning of the company in the long term.

It is proposed to understand the system of factors of the company as any sources or unique values that give it an advantage over competitors and opportunities to attract potential customers and retain regular customers. There are three directions in economics, according to which competitive advantages of any company are formed in modern conditions:

1. Institutional (the source of competitive advantage is the integration of an enterprise into the business environment, its information field and the system of industry and market relations).

2. Market (the specifics of the industry, the type and scale of competition, the behavior of the enterprise itself in the market).

3. Resource (combination of enterprise resources, both tangible and intangible, and their management system).

The Ukrainian scientist T. Halimon (Halimon, 2017) in his research highlights the modern world experience of successful functioning of well-known corporations that have achieved a competitive advantage through the active use of a number of innovative methods of transforming their business (Lean production, 6 $\sigma$, 4Re, BPR) as sources of competitiveness advantages. Measures to ensure the competitive advantage of the enterprise to achieve the necessary level of competitiveness can be: the formation of the flow of value creation, extensive development of innovation, customer focus, the development of innovative communications for customers, synchronization of technological and managerial processes.
V. Vasilenko and T. Tkachenko (Vasilenko \& Tkachenko, 2004) note that the most typical factors for creating competitive advantages are: new technologies; changes in the structure and cost of individual elements of the technological chain of production and sale of goods; new consumer demands; the emergence of a new market segment; changing the rules of the game in the market.

According to L. Shekhovtsova (Shekhovtseva, 2001), it is reasonable to refer such factors of production as: natural resources; favorable conditions for the production of goods; qualified workforce; effective investments in educational technologies and licenses; creation of new products, production processes and other innovations; use of created wealth to ensure economic growth to the factors of competitive advantage of the company.

We believe that the main means of achieving competitive advantage for consulting companies are competitive strategies. They are based on and implemented on approaches related to the management and strengthening of the long-term competitive position of the company on the services market. Well-known foreign scientists G. Hamel, K. Prahalad (Hamel \& Prahalad, 2002) note that the formation of a company's competitive strategy is to create a future competitive advantage faster than competitors copy what the company uses today. In the works of J.-J. Lamben (Lamben, 2008), M. Porter (Porter, 2005) emphasized the presence of a systemic connection between the components of market-oriented enterprise management and competitive strategies, which substantiates the organizational and economic principles of the development of business structures and their competitors in accordance with the industry format.

The relationship between the competitive strategy and the process of formation of competitive advantages of the company in the Ukrainian market of services is shown in Figure 1.

We believe that competitive strategies implement the objectives outlined by company management in the corporate and business strategy, which will be reflected in the activities of the company at the functional and operational levels. In these circumstances, the competitive strategy includes the process of forming competitive advantages, the strategy of ensuring the competitive position of the enterprise in accordance with the set strategic goals and objectives, and the strategy of competitive behavior in accordance with a set of interrelated measures of competitive struggle.

In the process of providing competitive strategies, business managers must clearly identify all the activities that will enable the enterprise to make better use of available resources, such as through the introduction of technology, better modernization, 


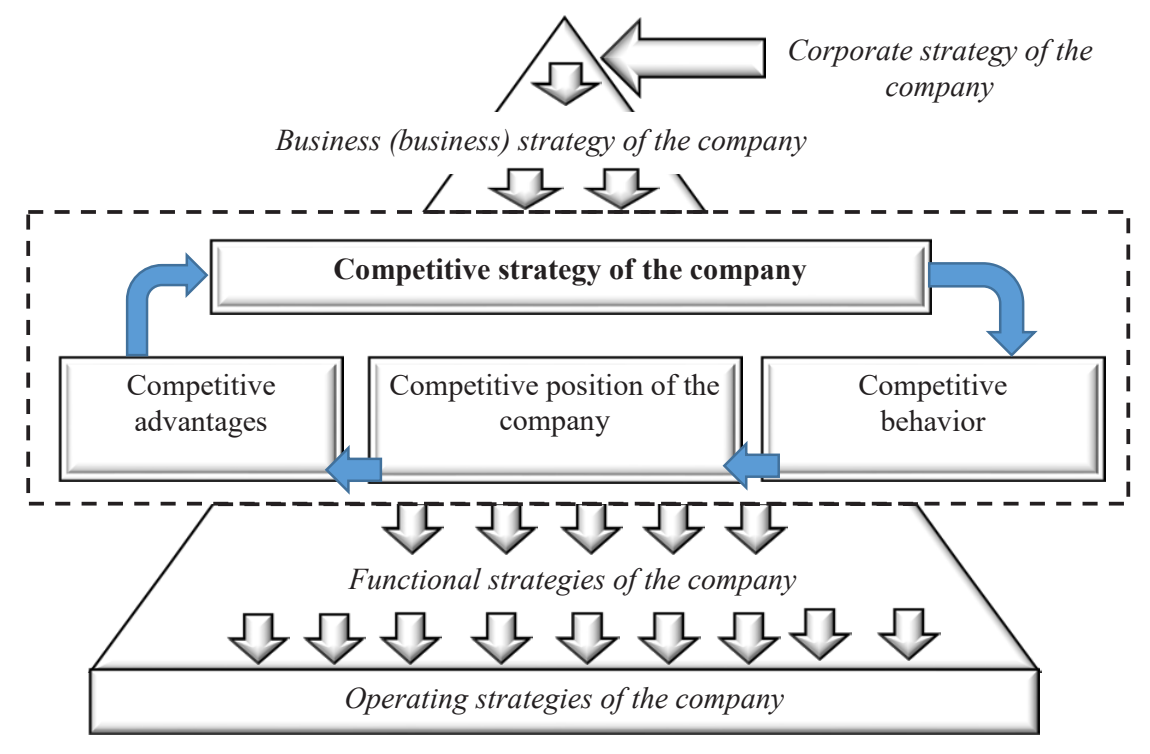

Figure 1. The relationship between competitive strategy and the process of forming the company's competitive advantage

Source: built by authors

employee motivation or effective management of the enterprise, among the existing strategic alternatives.

Scientists have proposed various options for the use of competitive strategies for specific areas. So in the works of M. Porter (Porter, 2005) universal competitive strategies (cost leadership, differentiation, focusing) are presented.

Japanese analyst and consultant K. Ohmae (Ohmae, 2007) created his own classification of competitive strategies, which divided into success factors: relative advantages; aggressive initiative; strategic level of freedom. Within this model, he identifies the key success factors of the company in the so-called "strategic triangle" ("Corporation", "Customer", "Competitors"). In contrast to M. Porter's classification, $\mathrm{K}$. Ohmae's classification is aimed at finding new opportunities.

The study by W. Chan Kim and G. Mauborgne (Kim \& Mauborgne, 2005) "Competitive Strategies of the Blue and Red Ocean" is interesting, the main purpose of which is to provide leadership among other players in the chosen field of competition. Chang Kim and G. Mauborgne propose to view the market universe as two oceans, red and blue. The "red ocean" symbolizes the now well-known industries, whose boundaries are defined and the rules of the game are known to all. The blue ocean is an untapped market that offers unlimited growth and high profits. These are industries that do not yet exist, where no one is threatened by competition because the rules of the game have not yet been formulated.

F. Kotler (Kotler \& Keller, 2012) identified four competitive strategies based on the assessment of market share owned by the organization:
1) The "Leader" of the market. He occupies a leading position; it is natural for him to strive to expand sales. The leader may also pursue a defense strategy (to protect his market destiny) by creating high barriers to market entry.

2) The "Challenger" (Contender for Leadership) challenges his competitors and seeks to take the place of the leader himself. He can organize a frontal (who is stronger) or flank attack (attack on weaknesses). Usually the challenger secures a price advantage. Provocations are possible in order to identify the "pain threshold" and weaknesses.

3) The "Follower" (Following the leader) sees advantages in "peaceful coexistence" with the market leader. He works in those segments where he can better use his capabilities and the advantages of small business. 4) "Nichevik" (Specialist) aspires to become "the biggest fish in a small river" and links its future to a strategy of specialization.

Practical aspects of the formation of competitive advantages taking into account competitive strategies are offered by the example of companies providing consulting services in Ukraine.

\section{Case studies}

In Ukraine, researchers have tried to segment the market for consulting services by various criteria: industry affiliation of enterprises-customers, the functional purpose of consulting services, by territorial location of consulting companies, the size of consulting companies and the like.

Despite the sufficient number of proposals on segmentation and evaluation of consulting services 
market, it is still difficult to estimate the size of this market in Ukraine using statistical data. In this regard, in 2017 Ukrainian scientist N. Yevtushenko (Yevtushenko, 2017) assessed the degree of maturity of the domestic consulting market according to the State Statistics Service of Ukraine within the code of economic activity (KVED) M "Professional scientific and technical activities", in which types of services are structured into groups of similar areas:

I group: activities in the field of law, accounting, architecture and engineering, technical testing and research, activities of head offices (head offices), management consulting;

II group: advertising and market research, other professional, scientific and technical activities, veterinary activities;

III group: research and development.

Let's analyze the dynamics of the realized volume of consulting services in Ukraine (Figure 2).

According to the data presented in Figure 1, it found that periods of rise and fall of the consulting market reflect the results of economic and political stability in Ukraine. Thus, the high demand for consulting services for the period 2010-2020 was recorded in 2013 - 49084.9 million UAH, and the lowest - in 2015, when the volume of sold consulting services decreased by 35959.2 million UAH and amounted to 13125.7 million UAH at the end of 2015 . In the period 2015-2020, the demand for consulting services is 21231.8 million UAH. However, in 2020, during the global pandemic COVID-19, the demand for consulting services in Ukraine slowed down, which can be seen in the dynamics of the volume. Thus, the volume of services sold by consulting companies in Ukraine in the period 2018-2019 increased by 6578.2 million UAH, while the volume of these services increased in 2020 only by 2368.5 million UAH relative to 2019 .

Today, during the crisis in the Ukrainian economy, it is not so easy for consulting companies to return the desired demand for consulting services where the main customers are industrial and engineering enterprises, as well as other large enterprises (Figure 3).

Economic analysis of consulting services market in Ukraine revealed its immaturity and instability in relation to the world market of consulting. It

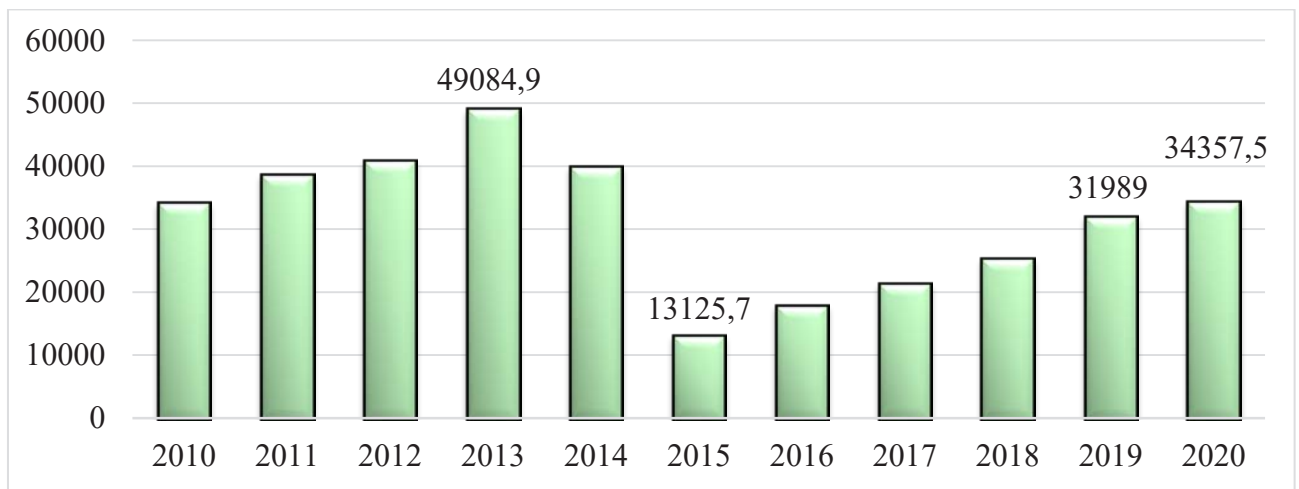

Figure 2. Dynamics of realization of consulting services in Ukraine (2010-2020), mln. UAH

Source: built by authors based on (Yevtushenko, 2017; 2019), (State Statistics Service of Ukraine, 2010-2020)

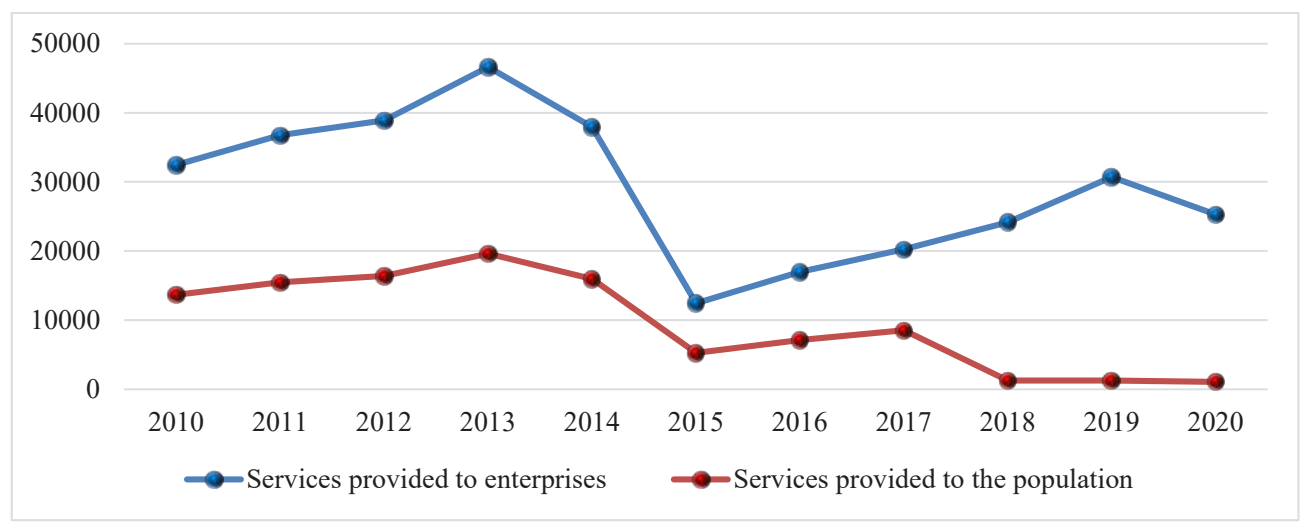

Figure 3. Dynamics of the services of consulting companies to enterprises and the population of Ukraine (2010-2020), mln UAH

Source: built by authors based on (Yevtushenko, 2017; 2019), (State Statistics Service of Ukraine, 2010-2020) 


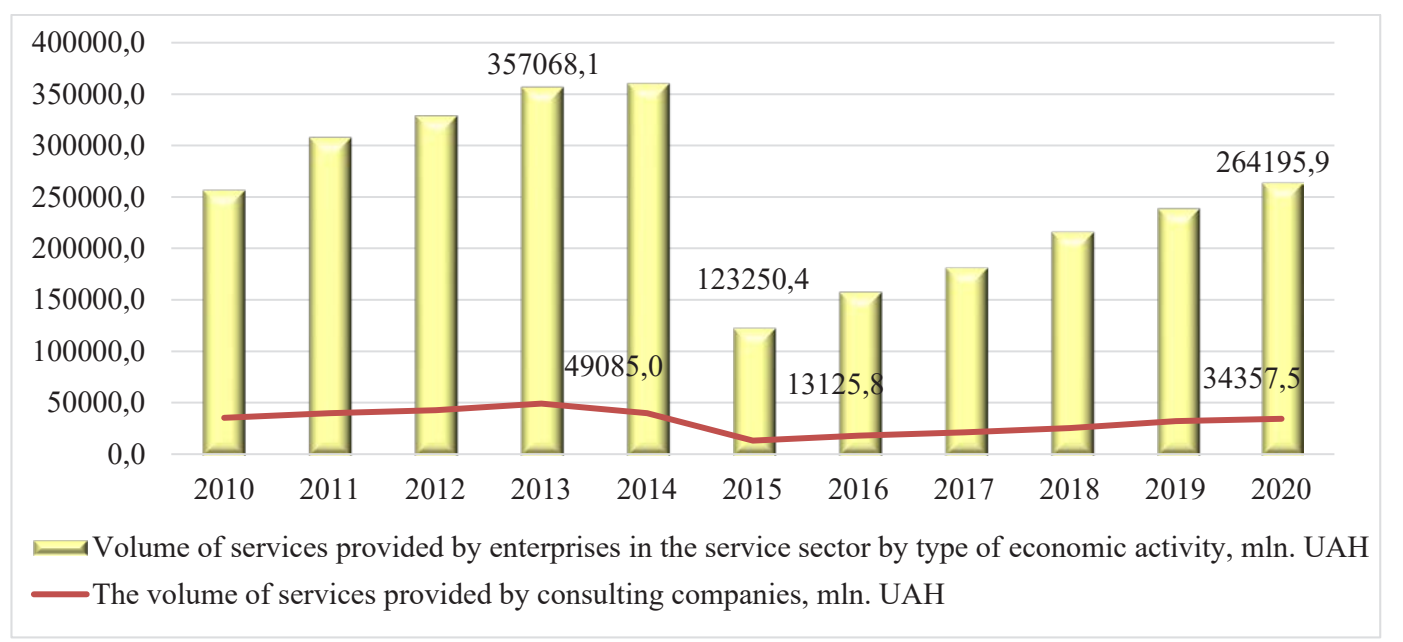

Figure 4. Dynamics of consulting services in the total volume of services in Ukraine (2010-2020), mln UAH

Source: built by authors based on (Yevtushenko, 2017; 2019), (State Statistics Service of Ukraine, 2010-2020)

was revealed that the share of consulting services market is insignificant and fluctuates within $11-13 \%$ of total market volume (Figure 4), while in the economies of developed countries consulting is a separate branch of activity, which services are in demand.

Economic analysis of the consulting market in Ukraine has revealed its immaturity and instability in relation to the global consulting market. The reasons affecting the development of the consulting market in Ukraine and the demand for consulting services include (Yevtushenko, 2019):

- the difficult macroeconomic situation, exacerbated by the political and socio-economic crisis, as well as military actions in the east of the country;

- low level of solvency of customers of consulting services;
- insufficient popularization of consulting services and insignificant demand for them;

- lack of legislative acts on the regulate consulting activities;

- lack of methodological support for service quality criteria and assessment of the usefulness of consulting;

- distrust of consulting companies due to limited data on the effectiveness of their activities;

- low percentage of guarantees of a specific result and a positive effect from consulting;

- lack of experience of enterprises in working with professional consultants;

- failure to fully comply with the confidentiality conditions by the consultants.

Checking of forecast of consulting services market development shows that in short-term perspective

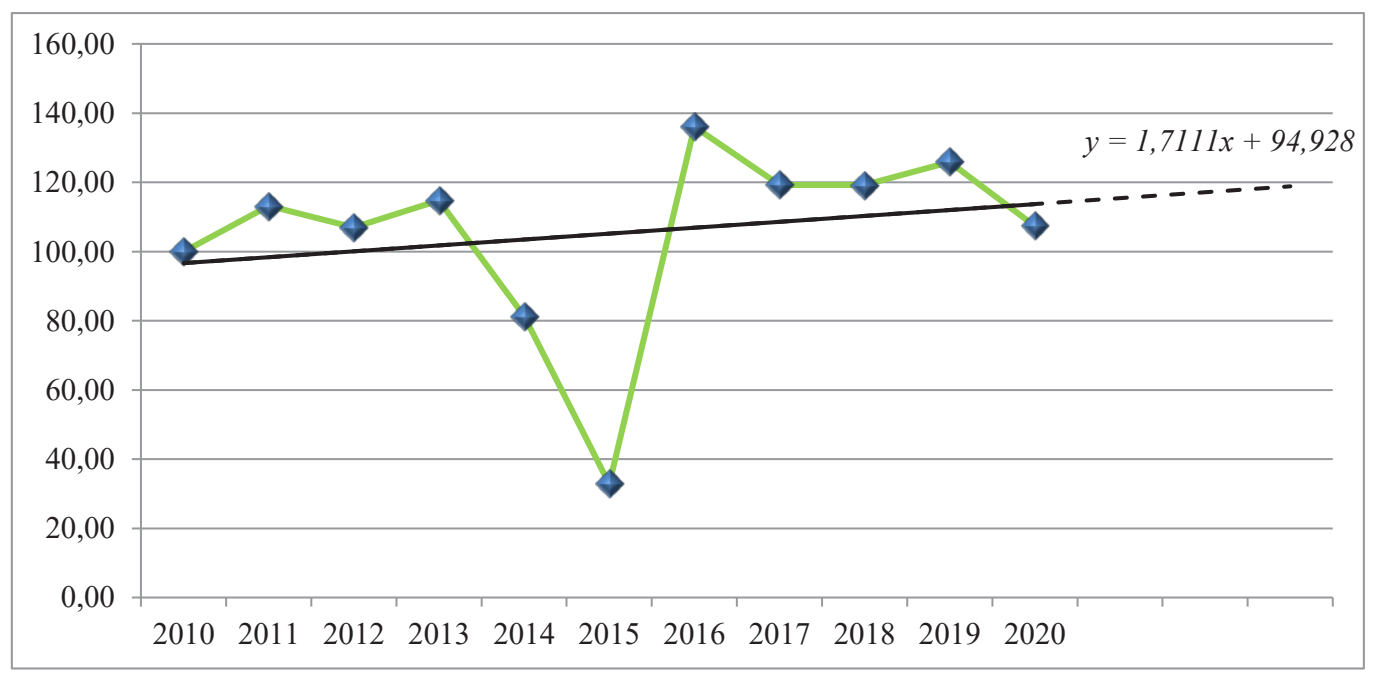

Figure 5. Growth rate of consulting market in Ukraine (2010-2020), \%

Source: built by authors based on (Yevtushenko, 2017; 2019), (State Statistics Service of Ukraine, 2010-2020) 
positive stabilization of external economic and political factors gives results of tendencies of Ukrainian consulting industry development (Figure 5).

Consulting in Ukraine, as well as in other countries around the world, was not protected from the economic consequences of the global crisis COVID-19. The growth rate of consulting market in Ukraine decreased by $18.5 \%$ in 2020 compared to 2019. According to research, the global consulting market during the pandemic also declined by $8 \%$ in 2020 (IBISWorld, 2021).

Despite its immaturity, the situation in which the Ukrainian consulting market at the end of 2020 showed the role of management consultants, responsible for leading companies to overcome disruptions. Therefore, management consulting is becoming more important type of services in Ukraine than ever before, especially its segment - digital consulting (IT consulting).

\section{Research results}

In 2020 Clutch experts evaluated 102 Ukrainian consulting companies whose services are in demand. The following indicators were used as evaluation criteria (Clutch, 2021):

1) Customer reviews.

2) Clients and company experience (the type and quality of clients the company works with, cases demonstrating the company's experience in different areas: projects, services, industries were taken into account.

3) Market presence and awards:

- Marketing efforts: "How clearly and professionally is the company presented on the Internet?"

- Reputation: "Does the company have a solid reputation in its industry?"
- Geographic presence: "Where is the company located?"

- Awards: "Has the company received any awards?"

- Social media presence: "Does the company have a social media page?"

- Leadership: "Does the company demonstrate efforts to innovate in its industry?"

In the process of evaluation, the experts selected the 15 best consulting companies in Ukraine, the data for which are presented in Table 1.

Based on the results of the expert assessment the leadership matrix was formed, taking into account the typologies of competitive strategies of F. Kotler. The matrix is an interactive graph of consulting companies' capabilities in relation to their competitive positions on the market (focus) (Figure 6).

The leadership matrix allowed to determine the place of each of the 15 consulting companies in one of the presented squares "Leader", "Challenger", "Follower", "Nichevik" and to form their capabilities in accordance with the competitive strategies of F. Kotler.

In the square of the matrix "Leader" of the surveyed companies only one - "Reprezent" (1), the types of its services are diversified: Business consulting - 35\%, Custom software development; Graphic design - 30\%; Corporate training - 35\%. This company has a high focus on desired service, provides clients with services at a high professional level, receives a lot of positive feedback from clients, and accompanies its business with competitive strategies to expand the market and protect its share in it.

The "Challenger" quadrant includes two companies: "Rosedome" (2) and "Finmodelslab" (6). In the activity of "Rozdoum" IT-consulting services are carried out $80 \%$, and in the activity of "Finmodelslab" dominate the services of financial consulting - up to $90 \%$. These companies provide professional services

Table 1

Top 15 consulting companies in Ukraine (2020)

\begin{tabular}{|l|c|c|c|c|}
\hline \multicolumn{1}{|c|}{ Ukrainian companies } & Reviews & Clients \& Experience & Market Presence & Location, \\
\hline 1. Reprezent & 16,3 & 8,8 & 7 & Kiev \\
\hline 2. Rozdoum & 16,6 & 8,2 & 8,5 & Kharkov \\
\hline 3. SalesTech & 17,4 & 5 & 6,9 & Kiev \\
\hline 4. Addition Advisory & 16,9 & 5 & 6,8 & Kiev \\
\hline 5. The Arbridge & 17,2 & 5 & 6,8 & Lviv \\
\hline 6. Finmodelslab & 16,3 & 7 & 8,4 & Kiev \\
\hline 7. Pragmatic DLT & 16,3 & 5 & 7,1 & Odessa \\
\hline 8. Creative Cooperative & 16,7 & 6,6 & 7,3 & Kiev \\
\hline 9. Fiddle.Digital & 16,9 & 6 & 6,8 & Kiv \\
\hline 10. Azon5 & 17,2 & 5 & 6,9 & Lviv \\
\hline 11. A-HR & 16,4 & 5 & 7,4 & Kiev \\
\hline 12. Keplercode & 16,4 & 5,7 & 7,2 & Kiev \\
\hline 13. Indigo Tech Recruiters & 16,3 & 5 & 6,8 & Kharkov \\
\hline 14. Nullgravity & 16,8 & 5,9 & & \\
\hline 15. Pragmaspace & 16,3 & & & \\
\hline
\end{tabular}

Source: built by the authors based on data (Clutch, 2021) 


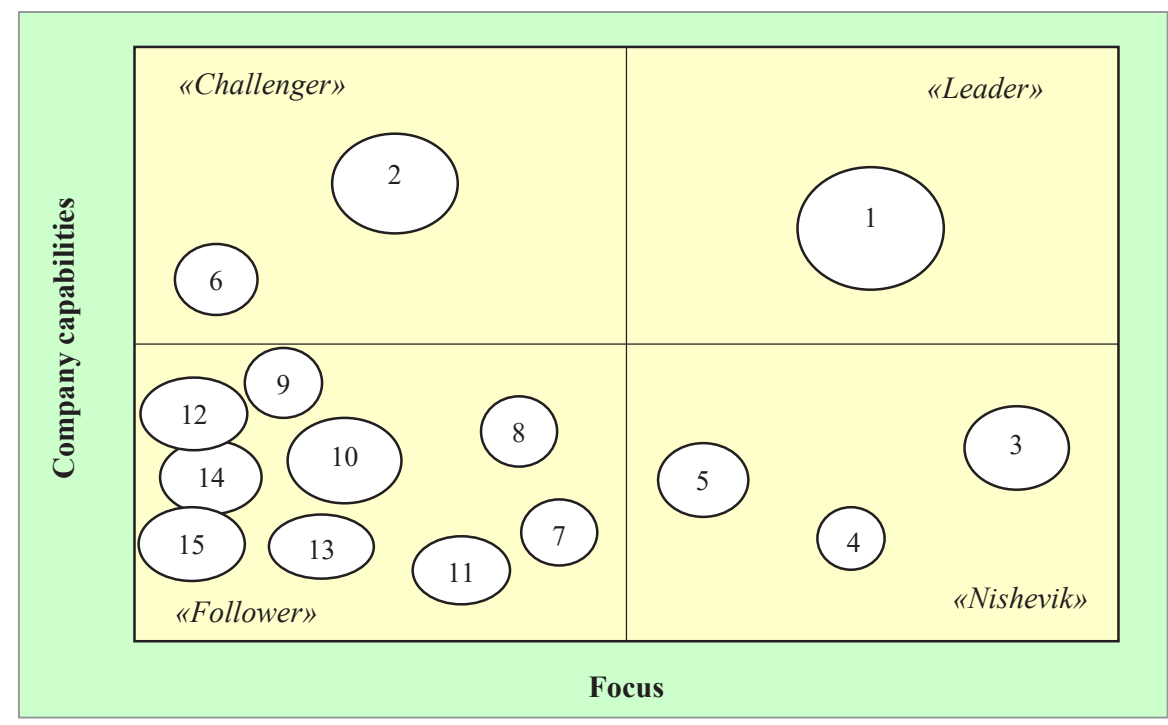

Figure 6. Leadership matrix of Top-15 consulting companies in Ukraine, taking into account the typology of competitive strategies by F. Kotler (2020)

Source: built by authors based on (Clutch, 2021)

in a narrow direction of consulting, receive good reviews, but have a low level of focus on the desired service. To strengthen their competitive position in the market, these companies use any active competitive strategy, most often a flank strategy, although they can afford a guerrilla competitive strategy as well.

Square - "Nishevik" includes three companies: "Sales Tech" (3), "Addition Advisory" (4), "Arbridge" (5). All of these companies provide IT-consulting and management consulting services. For example, "Sales Tech" sells up to $50 \%$ of business consulting services and up to $40 \%$ of marketing and digital strategy development services. "Addition Advisory" provides up to $40 \%$ of business consulting and up to $40 \%$ of digital marketing. The "Arbridge" provides up to $70 \%$ of IT consulting and IT strategy services, and only $30 \%$ of management consulting. "Nishevik" companies have a moderate ability to provide consulting services, have a high focus on the desired service, and receive good feedback from clients because they have a long-standing specialization in their chosen service areas.

The last square of the Leadership Matrix "Follower" includes most of the consulting companies in the Top 15 rating in Ukraine: "Pragmatic DLT" (7), "Creative Cooperative" (8), "Fiddle.Digital" (9), "Azon5" (10), "A-HR" (11), "Keplercode" (12), "Indigo Tech Recruiters" (13), "Nullgravity" (14), "Pragmaspace" (15). These are the so-called newcomers, companies that have recently entered the service market, provide IT consulting services demanded by time and events, and have a moderate ability to provide their services, a low level of attention to the desired service and strong customer feedback. Most of these companies use a competitive strategy of following in the footsteps of the leader, but there are also those that try to outperform their competitors by creating their own competitive advantages.

To increase the level of competitiveness of Ukrainian consulting companies and the distribution of their services in the domestic and foreign markets, it is necessary to solve the following tasks (Yevtushenko, 2019):

1. Agreeing at the legislative level the standards of consulting services (unified classification of consulting services) and methodological foundations for the formation and implementation of the mechanism of consulting interaction, as well as criteria for the quality of consulting services and methods for their assessment.

2. Increasing the interest of the state in the participation of consulting companies in state and regional strategic programs for socio-economic development, as well as in public-private partnership programs.

3. Support for the development of human capital as the main intellectual resource of a consulting company, taking into account an agreed system for managing its potential.

4. Use of effective organizational and management structures in the process of implementing consulting interaction based on the organizational model of corporate culture and the strategy of human capital behavior of the consulting company.

5. Taking into account the system of criteria for evaluating and encouraging personnel to improve the quality of the provision of consulting services in the process of consulting interaction. 
6. Coordination of consulting interaction processes in accordance with the quality management system and the effectiveness of functioning because of a synergistic effect.

7. Application of a system for evaluating the results of consulting interaction using knowledge management programs.

8. Effective use of management tools to promote consulting services.

\section{Recommendations}

We agree with the opinion of scientists about important groups of factors that create a competitive advantage for each individual company in the market. However, we support the viewpoint of J.-J. Lamben, who identified three factors that form the competitive advantage of the company (Lamben J-J, 2008): 1) product quality (excellent product quality with increased value for the consumer); 2) production costs (benefits of price and cost control, administration and product management); 3) key competencies (special skills or technologies that create a unique uniqueness for the consumer).

In his works, the scientist $\mathrm{N}$. Yevtushenko (Yevtushenko, 2019) recommended to refer to the sources of formation of the competitive advantages of a consulting company: key competencies of consultants; quality of consulting services; the productivity of the consulting company and its results (Figure 7).

To strengthen existing competitive advantages and to carry out procedures to update them, it is advisable to take into account the following information:
- life cycles of competitive advantages, which will reveal the moment of the need to strengthen the competitive advantage in case one of the existing ones has already expired, is in decline and should be restored;

- market requirements, because consumers dictate their terms and win the competition, and the company tries to take into account these needs as much as possible;

- competitive advantages of competing companies, other consulting companies and their weaknesses, which allows the company to make effective decisions on how to take into account variable characteristics in the process of updating existing competitive advantages that have not yet been used by competitors.

In the works of N. Yevtushenko it is given that the main competitive advantage of any consulting company is the key competencies of consultants. Consultants are the intellectual resource of a consulting company. She offered a set of consultant competencies in the form of an "Intellectual Resource" package based on the "Effective Consultant" model for a management consultant, an expert consultant, and a specialist consultant. This will effectively affect the growth of company productivity (Yevtushenko, 2017; Yevtushenko, 2019). The Efficient Consultant model is an abstract analysis of the process of transforming knowledge into an intellectual product - consultant competence. This model substantiates the direct dependence of consultants' knowledge structure on their competencies. (Yevtushenko, Kuzminska \& Kovalova, 2021).

Due to the absence of the concept of "Standard of consulting services" in the state regulations of Ukraine, as well as given the foreign experience of managing consulting companies, its necessity is justified.

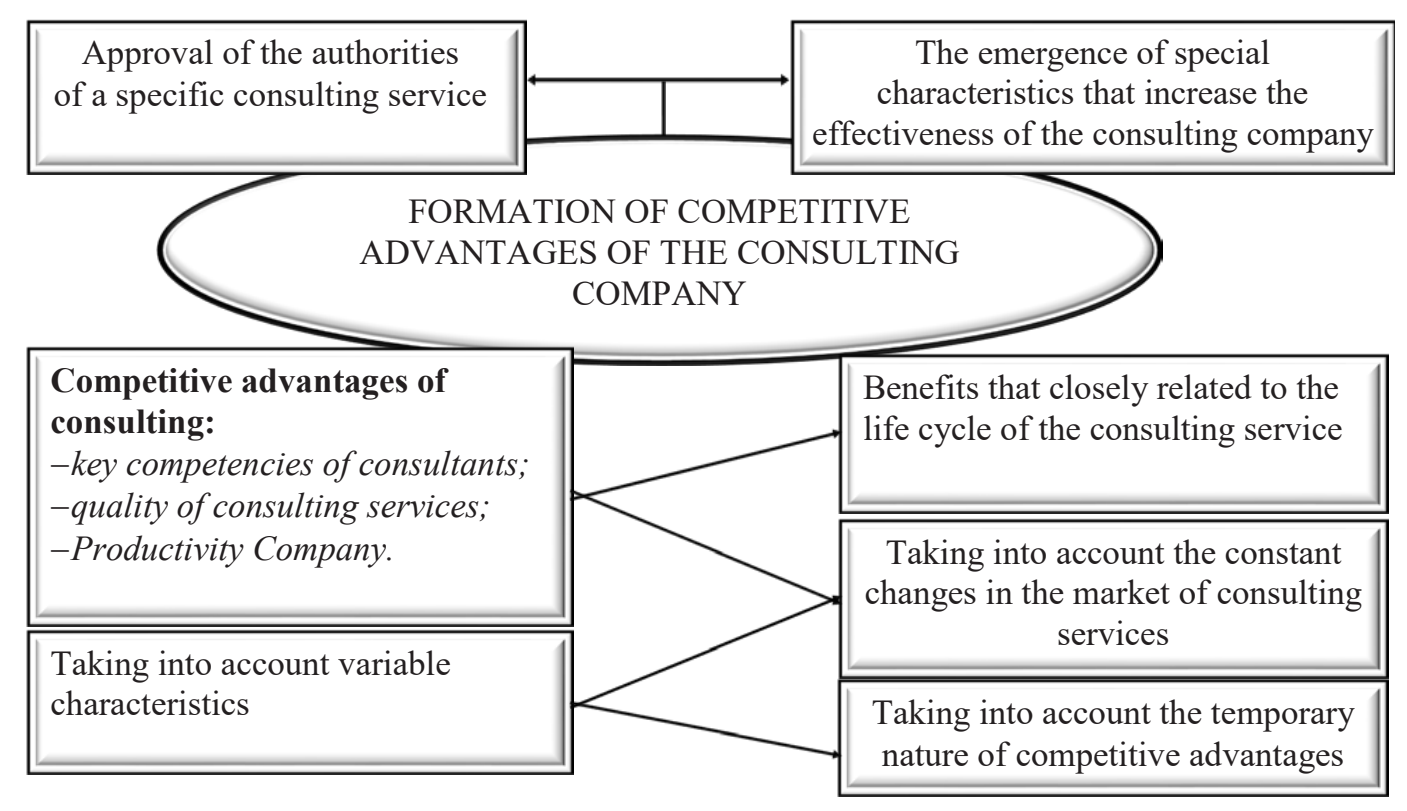

Figure 7. Factors in the formation of the competitive advantages of consulting companies

Source: (Yevtushenko, 2019) 


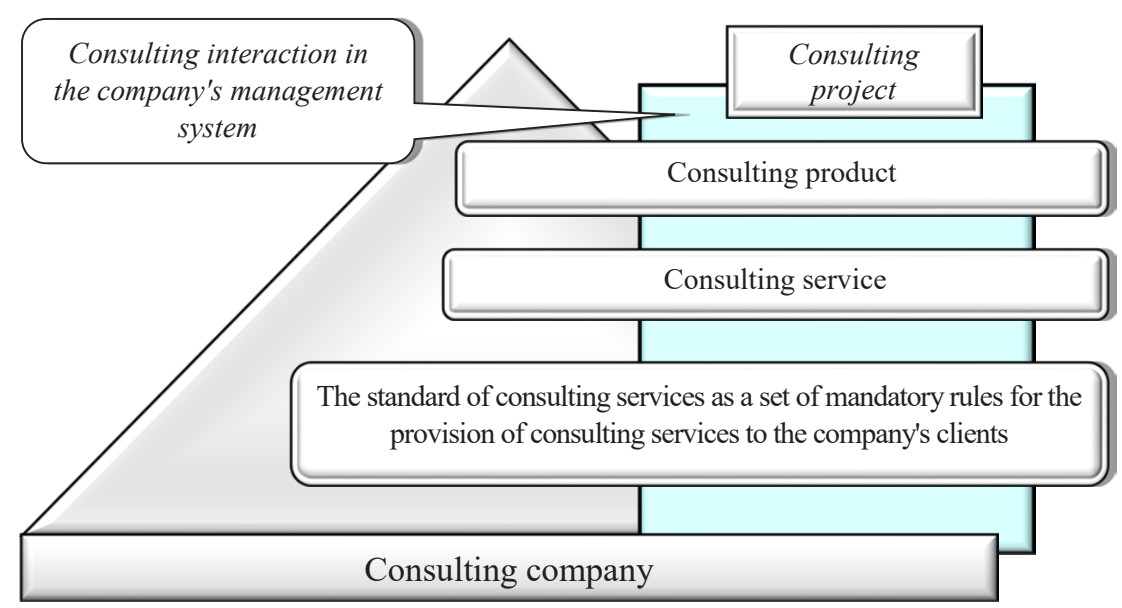

Figure 8. The place of the standard of consulting services in the process of providing consulting services Source: (Yevtushenko, 2019)

The content of the concept "Standard of consulting services" N. Yevtushenko proposes to consider as a set of mandatory rules for the provision of consulting services that will guarantee a high level of quality and professionalism of consultants at all stages of the implementation of the consulting project (Yevtushenko, 2019) (Figure 8).

The formation of the quality of consulting services should be based on criteria. They will be spelled out in the internal documents of the company and approved by the company management. In the rules that are prescribed at the state level in the normative-legal acts of Ukraine in the sphere of consulting services market regulation. To the basic rules for the provision of consulting services is proposed such as (Yevtushenko, 2019):

1) communicative interaction with clients;

2) quality of services;

3) corporate behavior;

4) ethical standards of the consultant;

5) certification of consultants;

6) improving the professionalism of consultants;

7) application of forms and methods of Public Relations in order to increase the popularity in the market of consulting services;

8) cooperation (partnership) within the professional association of consulting companies.

The standard of consulting services is necessary for Ukrainian consulting companies in order to form and maintain a high level of quality of consulting services, which will contribute to the professional activity of consultants and increase the demand for such services.

\section{Conclusions}

According to the results of the study, it was found that despite the large number of players, the consulting services market in Ukraine in the period 2010-2020 has not yet been finally formed, the demand for consulting services is unstable, and the level of competitiveness of Ukrainian consulting companies does not meet the requirements of world leaders. The main reasons are macroeconomic and political factors During the strategic analysis of consulting companies in the Ukrainian market of services in 2020 the Top 15 were selected, of which one company was in the "leader" segment, and among the stable "niches" only three, the rest entered the market recently, but already have the desire to follow the leader. The main activities of these companies are IT consulting (or digital consulting) and HR consulting. Despite this narrow focus, consulting companies today have the important task of spreading digitalization among clients and implementing innovative digital technologies in their operations. This is especially true during the global COVID-19 pandemic.

We believe that the market of consulting services in Ukraine has prospects for development in the near future due to the tangible flexibility of leading consulting firms with their freedom from fixed capital and high dependence on resources. Stabilization of the service market in Ukraine is also possible with the growth of economic activity of industrial enterprises, the participation of consulting in the formation of public-private partnerships and investment attractiveness of the country. At the same time, the main advantages of consulting companies include the competence of consultants.

Clients expect consultants to have specialized knowledge, and this perceived market gap in niche knowledge will be easily exploited by newcomers. We argue that consulting in Ukraine requires institutional improvements and the introduction of a standard for consulting services. This will entail the revision of the management system in companies to maintain their competitive advantage. In the long term it will help consulting companies in Ukraine to increase both their own profits and profitability of their clients. 


\section{References:}

Aleshnikova, V. I. (2000). The concept of development of management consulting in the Russian Federation (Theoretical and methodological aspect). Doctoral dissertation. Moscow: State University of Management.

Azoev, G. L., \& Chelenkov, A. P. (2000). Competitive advantages of the firm. Moscow: Tipografiya NOVOSTI.

Balabanova, L. V. (2002). Marketing. Donetsk: DonDUET. (in Ukrainian)

Bondarenko, S. M., \& Lisovsky, M. Yu. (2017). Competitive advantages - unique features of modern enterprises. Scientific Bulletin of UNU, 15, 42-45. (in Ukrainian)

Blinov, A. A., \& Dresvyannikov, V. A. (2013). Management consulting: Moscow: Dashkov and $\mathrm{K}^{\circ}$.

Block, P. (2007). Flawless consulting. St. Petersburg: Peter, 170.

Clark, T. (1995). Managing Consultants: Consultancy as the Management of Impressions. Bristo: Open University Press.

Clutch (2021). Top Ukraine Consulting Companies. Available at: https://clutch.co/ua/consulting/leadersmatrix?facets $=\% 2$ fua $\% 2$ fconsulting

Davidenko, V. V. (2006). Formation and implementation of consulting support of enterprises. Problems of Science, 7, 32-36.

Dolzhansky, Z. I., \& Zagorna, T. O. (2006). Competitiveness of the enterprise: textbook. Kyiv: CUL, 384. (in Ukrainian)

Elin, K. V. (2012). Competitive advantage management model in the concept of controlling. TOGU Bulletin, 1(24), 207-212.

Fathudinov, R. A. (2004). Managing the competitiveness of the organization. Moscow: Izd-vo «Eksmo».

Greiner, L. E., \& Metzger, R. O. (1983). Consulting to management. Englewood Cliffs, NJ, Prentice Hall.

Gudz, O. E. (2013). Financial strategies to ensure the competitiveness of the enterprise. Financial space, 4, 97-103. (in Ukrainian)

IBISWorld (2021). Retrieved from: https://www.ibisworld.com/solutions/ibisworld-for-consulting-firms /

Khalimon, T. (2017). Conceptual principles of enterprise competitiveness management. Intelligence XXI, 3, 57-63. (in Ukrainian)

Hamel, G., \& Prahalad, K. (2002). Competition for the Future. Building the markets of tomorrow. Moscow: Olymp-Business.

Kubr, M. (1992). Management consulting. Moscow: Interekspert.

Kipping, M. (1999). American Management Consulting Companies in Western Europe, 1910s - 1990s: Products, Reputation, and Relationships. Business History Review, 73/2, 190-220.

Kim, W. Chan, \& Mauborgne, R. (2005). Blue Ocean Strategy: From theory to practice. California management review, 3(47), 110.

Kotler, F., \& Keller, K. (2012). Marketing. Management. St. Petersburg: Peter "World of books".

Lamben, J.-J. (2008). Market-oriented management. St. Petersburg: Peter.

Levitska, A. O. (2012). Competitive advantages of the enterprise: essence and sources of formation. Bulletin of KNU Sciences, 4, 52. (in Ukrainian)

MacDonald, S. (2006). Babies and Babies: Management Consultants and First-Time Clients. European Management Journal, 24/6, 411-421.

Marinko, G. I. (2005). Management consulting: Textbook. Moscow: INFRA-M.

O'Mahony, J. (2010). Management consulting. Oxford: Oxford University Press.

Ohmae, K. (2007). Thinking a Strategist: The Art of Business in Japanese. Moscow: Alpina Business Books.

Porter, M. (2005). Competitive strategy: Methods of analysis of industries and competitors. Moscow: Alpina Books.

Rybakova, T. O. (2010). Features of the consulting project. Project Management and Production Development, 4, 39-44.

Science History Institute (2017). Available at: https://www.sciencehistory.org/historical-profile/arthur-d-littlewilliam-h-walker-and-warren-k-lewis

SeoSolution (2016). An inspirational story about the success of an American company McKinsey. Available at: https://seosolution.ua/blog/business-books/story-of-mckinsey.html

Shane, E. (1969). Process consultation: its role in the development of an organization. Reading, Massachusetts: Addison-Wesley.

Shekhovtseva, L. S. (2001). Competitiveness of the region: factors and method of creation. Marketing in Russia and abroad, 4(24), 11-16.

State Statistics Service of Ukraine. A lot of realizable parcels for regions by type of economic activity in Ukraine 2010-2020. Available at: http://www.ukrstat.gov.ua/ (in Ukrainian)

Teslyuk, N. P. (2005). Strategies of the enterprise on achievement of competitive advantages. Economics, finance, law, 11, 17-20. (in Ukrainian) 
Trofimova, O. K. (2002). Methods of ensuring the effectiveness of consulting services in industrial enterprises. The dissertation of the candidate of economic sciences. Kharkiv: National Aerospace University them. M. E. Zhukovsky "Kharkov Aviation Institute". (in Ukrainian)

Vasilenko, V. O., \& Tkachenko, T. I. (2004). Strategic management of the enterprise: textbook. Kyiv: Center for Educational Literature, 400. (in Ukrainian)

Verba, V. A., \& Reshetnyak, T. I. (2000). Organization of consulting activities. Kyiv: Kyiv National Economic University. (in Ukrainian)

Verba, V. A. (2012). Management consulting of enterprise development. Doctoral dissertation. Kyiv: Kyiv National Economic University named after Vadym Hetman. (in Ukrainian)

Voychak, A. V., \& Kamyshnikov, R. P. (2005). Competitive advantages of the enterprise: essence and classification. Marketing in Ukraine, 2, 50-53. (in Ukrainian)

Yevtushenko, N. O. (2019). Organizational and economic mechanism of consulting interaction of enterprises of Ukraine. Doctoral dissertation. Kyiv: State University of Telecommunications. (in Ukrainian)

Yevtushenko, N. O. (2017). Mechanism of consulting interaction of enterprises in the market of telecommunication services of Ukraine: monograph. Kyiv: SIC GROUP Ukraine. (in Ukrainian)

Yevtushenko, N., Kuzminskaya, N., \& Kovalova, T. (2021). Dependence of the knowledge structure of company employees on a set of competencies. Advances in Science, Technology and Engineering Systems Journal, 6(2), 699. DOI: https://doi.org/10.25046 / aj060281

Yuksvyarav, R. K., Khabakuk, M. Ya., \& Leimann, Ya. A. (1988). Management consulting: theory and practice. Moscow: Economics. 